\section{EDITORIAL \\ Agricultura en zonas áridas y semiáridas Agriculture in arid and semi-arid zones Pilar Carolina Mazuela Águila}

\title{
A. INVESTIGACIONES
}

Study on attitudes and perceptions of organic and non-organic coconut growers towards organic coconut farming

Estudio sobre la actitud y percepción hacia el cultivo orgánico en los productores de coco orgánico y no orgánico

Chaminda S. Herath, Rusitha Wijekoon

Evaluación de la satisfacción de clientes respecto de la calidad de atención en la Feria Libre $\mathrm{N}^{\mathrm{o}} 2$ de la comuna de Quinta Normal, Santiago de Chile

Customers' satisfaction assessment regarding to service quality of Feria Libre $N^{o} 2$ in Quinta Normal Municipality, Santiago, Chile

Luis Sáez Tonacca, Lidia Castro Ruiz, Carlos Díaz Ramírez

Prospección de la estimación de la evapotranspiración de referencia, bajo las condiciones del valle de Chaca, Arica-Chile

Research of the estimation of the evapotranspiration of reference, under the conditions of Chaca's valley, Arica-Chile

Amador Torres Hernández, Rodrigo Vásquez Vásquez

Relaciones de abundancia de órdenes de hexápodos terrestres en vegas altoandinas del desierto-transicional de Chile

Abundance relationships of orders of terrestrial hexapods in high-Andean peatlands of the transitional desert of Chile

Jorge Cepeda-Pizarro, Marta Pola L.

Presence of Phytophthora cinnamomi Rands. in avocado orchards in Azapa and Codpa valleys, Chile

Presencia de Phytophthora cinnamomi Rands. en huertos de palto en los valles de Azapa y Codpa, Chile

Germán Sepúlveda-Chavera, Ricardo Salvatierra-Martínez, Cristián Bilbao-Apata,

Paulina Sepúlveda-Ramírez, Marjorie Allende-Castro, Jorge Alache-González

Calidad de semillas en colectas y accesiones de Jatropha curcas L.

Seed quality in collections and accessions of Jatropha curcas $L$.

Cipriano Ramón Enciso-Garay, Francisco Agustín Vergara Ocampo,

Victoria Rossmary Santacruz Oviedo

Path analysis in multicollinearity for fruit traits of pepper

Análisis de ruta con multicolinealidad de las características de la fruta de la pimienta Anderson Rodrigo da Silva, Moysés Nascimento, Paulo Roberto Cecon, Moryb JLC Sapucay, Elizanilda Ramalho do Rêgo, Lidiane Aparecida Barbosa

\section{REVISTA DE AGRICULTURA EN ZONAS ÁRIDAS ARID ZONES AGRICULTURE JOURNAL UNIVERSIDAD DE TARAPACÁ ARICA-CHILE}




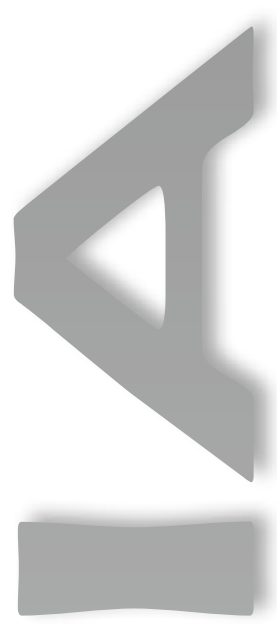

Effects of aluminum, nitrate and ammonium on the growth, potassium content and composition of amino acids in Stylosanthes

Efectos de aluminio, nitrato y amonio en el crecimiento, contenido de potasio y composición de aminoácidos en Stylosanthes

José Augusto Teixeira do Amaral, Alemar Braga Rena. Antonio Teixeira Cordeiro,

Edilson Romais Schmildt

Evaluación del rendimiento de nueve genotipos de quinua (Chenopodium quinoa Willd.)

bajo diferentes disponibilidades hídricas en ambiente mediterráneo

Grain yield of nine quinoa genotypes (Chenopodium quinoa Willd.) grown in

Mediterranean environments differing in water availability

Marco Garrido, Paola Silva, Herman Silva, Rocío Muñoz, Cecilia Baginsky,

Edmundo Acevedo

Uso de un polímero hidrófilo en chile Anaheim (Capsicum annuum L.)

bajo condiciones de invernadero

Use of a hydrophilic polymer in Anaheim pepper (Capsicum annuum L.)

under greenhouse conditions

Jesús López-Elías, Marco Antonio Huez L., Edgar Omar Rueda P., José Jiménez L.,

Fidencio Cruz B. y Oscar Garrido L.

Vegetative development and yield of the banana cv. 'Prata Anã' as a function of magnesium and potassium fertilization

Desarrollo y producción del banano 'Prata Anã' bajo fertilización con magnesio y potasio Inêz Pereira da Silva, José Tadeu Alves da Silva, Paulo Jorge de Pinho, Cleber Lázaro

Rodas, Janice Guedes de Carvalho

Variabilidad temporal de algunos parámetros físicos e hidroquímicos de un prado húmedo alto-andino del norte-centro de Chile

Temporal variability of some physical and hydrochemical parameters of a high Andes wet-pasture of north-central Chile

Jorge Cepeda-Pizarro

\section{B. NOTAS CIENTÍFICAS}

First report of tomato bacterial canker Clavibacter michiganensis subsp. michiganensis on tomato crops in Arica

Primer reporte de cancro bacteriano Clavibacter michiganensis subsp. michiganensis en plantas de tomate en Arica

Germán F. Sepúlveda Chavera, Ricardo Salvatierra Martínez, Claudio Sandoval Briones,

Robinson González Vásquez

Primeros registros de la araña saltarina Hasarius adansoni (Auodouin, 1826)

(Araneae: Salticidae) en Chile

First records of the jumping spider Hasarius adansoni (Auodouin, 1826)

(Araneae: Salticidae) in Chile

Andrés Taucare-Ríos

Survival analysis in plant pathology

Análisis de supervivencia en fitopatología

Cristiano Nunes Nesi, Silvia Emiko Shimakura, Paulo Justiniano Ribeiro Junior,

Louise Larissa May De Mio

\section{COMENTARIOS DE ACTUALIDAD}

La quinua (Chenopodium quinoa Willd), un tesoro andino para el mundo José Delatorre-Herrera, M. Sánchez, I. Delfino, M.I. Oliva

A. INFORMACIONES GENERALES 


\title{
EDITORIAL
}

\section{Agricultura en zonas áridas y semiáridas}

\author{
Agriculture in arid and semi-arid zones
}

Pilar Carolina Mazuela Águila

\section{Doctora \\ Universidad de Tarapacá, \\ Arica, Chile pmazuela@uta.cl}

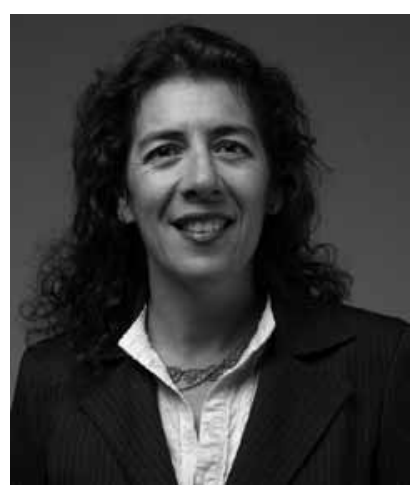

Doctor

University of Tarapaca,

Arica, Chile

pmazuela@uta.cl
Una de las características de las zonas de clima árido y semiárido es la baja disponibilidad de agua, cuantificada a base de la precipitación media anual, en relación con la evaporación de un área geográfica determinada. Cuando esta relación es menor a 0,65 se considera zona de clima árido y semiárido. Los factores que inciden en esta alta evaporación son la radiación solar incidente, la presión de vapor del aire, gran fluctuación de temperaturas diurna/ nocturna y la velocidad del viento. Los suelos de estas zonas son variables en profundidad, textura, $\mathrm{pH}$, conductividad eléctrica y fertilidad, siendo frecuente los suelos con perfil incipiente o poco desarrollado. Estos suelos acumulan sales solubles cuya distribución, composición y concentración depende de las características y flujo del agua en el perfil. En zonas con baja precipitación, la evaporación del agua deja en el suelo sales que, al no ser disueltas y redistribuidas, generan la salinización de los suelos. Los suelos de zonas áridas y semiáridas acumulan carbonato y la tasa de infiltración del horizonte cálcico depende del contenido de carbonato. La productividad de estos suelos depende de la capacidad de retención de agua, textura, profundidad y contenido de materia orgánica.

Se estima que, actualmente, un cuarto de la superficie terrestre corresponde a tierras áridas o semiáridas. De la superficie cultivada bajo riego, un
One of the characteristics of zones with arid and semi-arid climate is the low availability of water, which is quantified based on the relation between the mean annual precipitation and the evaporation in a given location. When this proportion is below 0.65 the area is considered to have an arid and semi-arid climate. The factors which determine this high evaporation rate are the incident solar radiation, the water vapor pressure of the air, the high day-night temperature fluctuation and the velocity of the wind. The soils of these zones are variable in depth, texture, $\mathrm{pH}$, electrical conductivity and fertility; frequently soil profiles are incipient or little developed. The soils accumulate soluble salts, whose distribution, composition and concentration depend on the soil characteristics and the flow of water in the profile. In zones with low precipitation, the evaporation of water leaves salts in the soil which, if not dissolved and re-distributed, generate soil salinization. The soils of arid and semi-arid zones accumulate carbonate, and the rate of infiltration of the calcium horizon depends on the carbonate content. The productivity of these soils depends on the water retention capacity, texture, depth and organic material content.

It is estimated that currently, one fourth of the terrestrial surface is composed of arid or semiarid lands. One fifth of the area cultivated with 
quinto está afectado por la salinidad. Esta tendencia a la desertificación de la Tierra y degradación de los suelos se debe, principalmente, al aumento de la población, a la alta presión en el uso de los recursos naturales, a malas prácticas agrícolas y a la acción del hombre, que ha utilizado las zonas más fértiles para construir ciudades. La tala de árboles, la destrucción de grandes superficies de selvas, el uso de gases con efecto invernadero, la industrialización y la masificación de sistemas de transportes dependientes del petróleo han contribuido al cambio climático, cuyo principal efecto es el aumento de las temperaturas medias del planeta, la disminución de las reservas de agua dulce y la salinización de un alto porcentaje de suelo arable.

El cambio climático es un fenómeno que obliga a generar nuevos conocimientos para el desarrollo de la agricultura en zonas marginadas por su clima árido y semiárido, debido a la necesidad de alimentar a una población que superó los 7 mil millones de personas. Además, el cambio climático supone que, en las próximas décadas, zonas de clima templado y suelos fértiles se verán afectados por la escasez de lluvias y una tendencia a la salinización. La biotecnología está en constante búsqueda de genes para producir en condiciones extremas, de ahí la necesidad de identificar y preservar la biota de los ecosistemas de zonas áridas y semiáridas.

Sin duda, la amenaza del cambio climático es una oportunidad para conocer, desarrollar y cuidar toda la biodiversidad de estos ecosistemas, tanto para obtener una mayor resistencia a sequías, sales, plagas y enfermedades, como la mejora en las características organolépticas, nutracéuticas, descontaminantes, farmacéuticas y cosméticas de la producción agrícola. En este desafío, la Universidad de Tarapacá quiere contribuir a la generación de nuevos conocimientos mediante IDESIA, Revista de Agricultura de Zonas Áridas y Semiáridas. irrigation is affected by salinity. This tendency to desertification of the earth and soil degradation is mostly due to the increase in the world population, the high pressure exerted on natural resources, poor agricultural practices and anthropogenic actions such as using the most fertile zones to construct cities. The cutting of forests, the destruction of large areas of jungles, the use of gases which produce greenhouse effect, industrialization and massification of petroleum-dependent transportation systems have all contributed to climate change, whose main effects include the increase in planetary mean temperature, the decrease of fresh water reserves and the salinization of a high percentage of tillable soil.

Climate change is a phenomenon which obliges us to generate new knowledge in order to develop agriculture in zones which have been marginal due to their arid and semi-arid climate, due to the need to feed a world population which has reached more than 7 billion. Climate change also predicts that in the next few decades, areas with temperate climate and fertile soils will be affected by scarcity of precipitation and tendency to salinization. Consequently, biotechnology is constantly searching for genes which allow production in extreme conditions, thus the necessity to identify and preserve the biota of arid and semi-arid ecosystems.

Undoubtedly, the threat posed by climate change is a challenge to know, develop and care for all the biodiversity in these ecosystems, both to obtain better resistance to drought, salts, pests and diseases and to improve the organoleptic, nutraceutical, decontaminant, pharmaceutical and cosmetic characteristics of agricultural production. The University of Tarapaca contributes to this challenge to generate new knowledge by means of IDESIA, Agricultural Journal of Arid and Semi-Arid Zones. 